This item was submitted to Loughborough's Research Repository by the author.

Items in Figshare are protected by copyright, with all rights reserved, unless otherwise indicated.

\title{
The media and 2010 campaign: the television election?
}

PLEASE CITE THE PUBLISHED VERSION

PUBLISHER

Oxford University Press on behalf of the Hansard Society / ( $)$ the authors

VERSION

AM (Accepted Manuscript)

LICENCE

CC BY-NC-ND 4.0

\section{REPOSITORY RECORD}

Wring, Dominic, and Stephen Ward. 2019. "The Media and 2010 Campaign: The Television Election?". figshare. https://hdl.handle.net/2134/13446. 
This item was submitted to Loughborough's Institutional Repository (https://dspace.lboro.ac.uk/) by the author and is made available under the following Creative Commons Licence conditions.

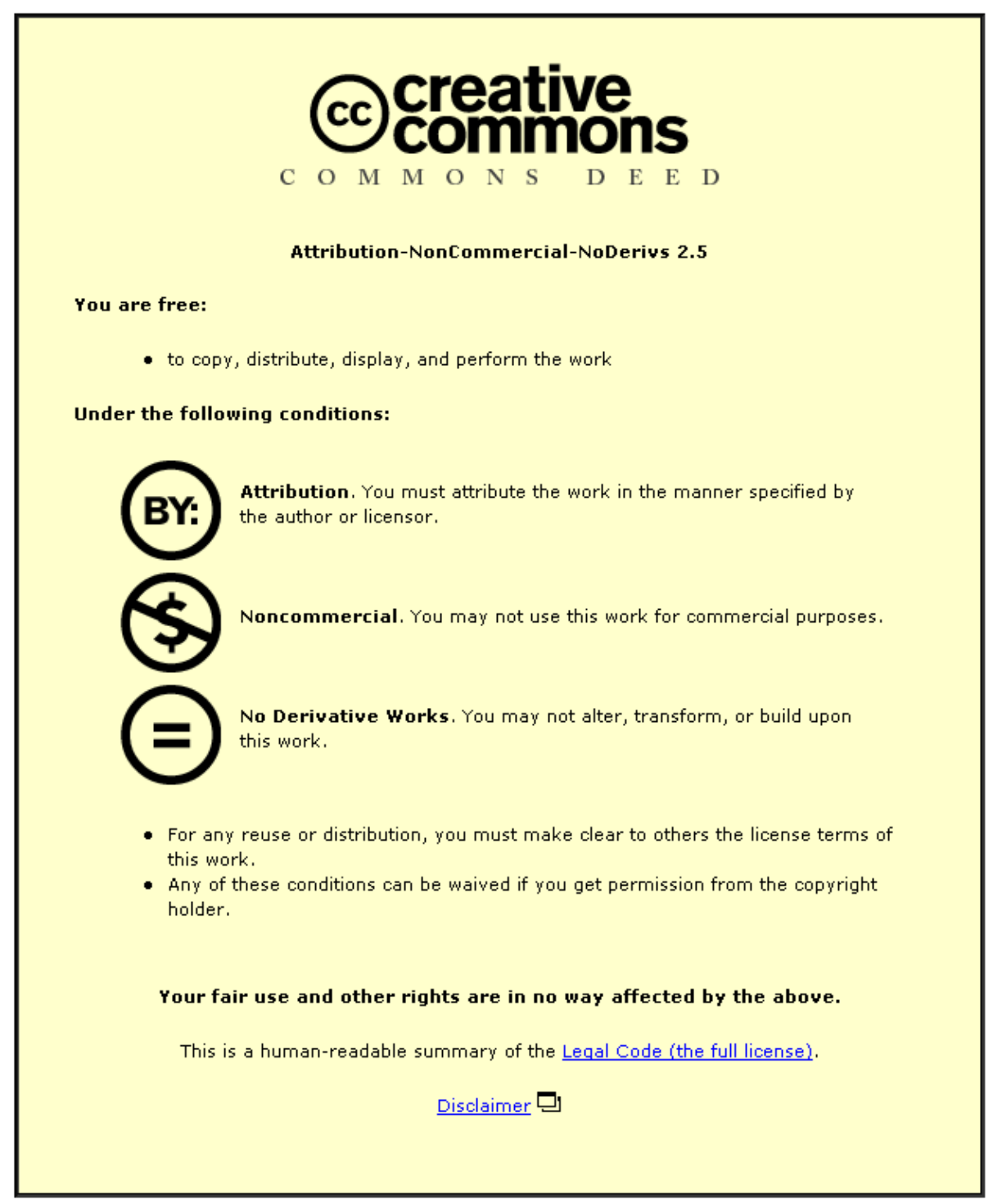

For the full text of this licence, please go to: http://creativecommons.org/licenses/by-nc-nd/2.5/ 
THE TELEVISION ELECTION? THE (TRADITIONAL) MEDIA AND 2010 BRITISH GENERAL ELECTION CAMPAIGN

DOMINIC WRING, LOUGHBOROUGH UNIVERSITY, UK

D.J.Wring@lboro.ac.uk

\section{Abstract}

The 2010 election was one of the most competitive campaigns of recent decades. The first televised leaders debates along with the rise of online social networking led to renewed speculation about the potential influence of the media in campaigns. By contrast the press appeared to revert to the pre mid-1990s form with strong support for the Conservatives and personal attacks on their opponents. This article concentrates on these two topics and specifically the influence of the leaders debates on the campaign and outcome of the election as well as how and whether press endorsements made much difference 
It is something of a cliché to say that the media play a major role in modern general elections but this was particularly the case during the 2010 campaign. From the broadcasting perspective, interest focussed on what influence the first televised leaders debates might have on the fortunes of the parties and the campaign generally - how far would this result in a further presidentialisation of campaigning and would any particular party/leader benefit? In relation to the oldest news medium - the press - interest centred on whether endorsement of the Conservatives by the Sun would make any difference and, more generally, whether Newspapers were of declining significance a the multi-media age? At the outset of the election, much speculation centred on the Internet, notably how prominent and important would social networking tools, such as Twitter and Facebook, be in the course of the campaign. Commentators drew on the American experience, where Obama's campaign was seen to have extensively deployed new technologies to great effect, to ask whether the same techniques would be used here.

In the event, it was television and the leaders debates that dominated the media agenda and became the centrepiece of the campaign. The significant rise in popularity of Nick Clegg following the first debate but the subsequent failure of the Liberal Democrats to turn this into votes and seats raises questions about how much difference the debates really made to the final outcome. Similarly, television also provided the other stand out moment of the campaign - the so-called 'Duffygate' incident - with Gordon Brown being recorded making derogatory remarks about a voter he had just met. Again, though, whilst this created a media storm, how much difference it really made is open to question.

\section{Cleggmania: the impact of the Leaders' Debates}

Contrary to pre-election hype this election this campaign was quite traditional in many 
respects. Despite falling audiences the established news media still continued to inform most voters. Television, in particular, contributed much because, for the first time, the three main leaders appeared together in the prime-time 'Prime Ministerial Debates'. Each edition attracted a mass audience, a rarity for any current affairs programming. The ITV debate opened the series and was seen by 9.68 million, placing it second only to the channel's top rated Britain's Got Talent and just above EastEnders and Coronation Street that week. ${ }^{\mathrm{i}}$ The by now lack of novelty together with the non-terrestrial platform contributed to only $2.21 \mathrm{~m}$ seeing the second instalment on Sky News together with an additional 1.39m watching the simultaneous broadcast on BBC News 24. This figure recovered to $7.43 \mathrm{~m}$ for the final encounter on BBC1. Cumulatively these represented huge, unprecedented audiences for general election related broadcasting of any kind; during this period the most popular television news bulletin attracted $5.56 \mathrm{~m}$ viewers.

The debates were a major innovation for a British general election although they are commonplace in other democracies. Previous incumbents and/or challengers had rejected the format for fear of providing their opponents with added momentum and copious negotiations prior to past elections had failed to assuage these doubts. There were still extensive discussions prior to this campaign over the debates' format and 76 rules for the contests agreed. The 2010 general election was to be different because it would be contested by three politicians contesting their first campaign as leader and who each calculated they could gain something from the debates. Gordon Brown had been installed unopposed as Labour leader in 2007 shortly before Labour's poll ratings began to plummet. Given this decline was partly caused by the economic downturn, the debates provided Brown with an ideal opportunity to justify and explain his response to the ensuing financial crisis. From the outset the Prime Minister attempted to position himself as the leader of most substance when, 
during the first encounter, he acknowledged 'if it is all about style and PR, then count me out' in an obvious criticism of his principal opponent David Cameron (if not predecessor Tony Blair). Cameron had been elected to lead the Conservatives in 2005 partly because of his presentational skills and, despite his party's longstanding lead in the polls, he also agreed to the debates because he evidently relished the opportunity to confront the less polished Prime Minister. For Liberal Democrat leader Nick Clegg the calculation was even more straightforward: the debates guaranteed him further exposure.

The debates had long been resisted by various politicians because they claimed such events were better suited to a presidential rather than parliamentary system. The decision to hold them has long term ramifications because if judged solely in terms of their success in attracting sizeable audiences it seems very likely that they will play a significant role in future campaigns. ${ }^{\text {ii }}$ That they happened this time was in part due to the threat by Sky to invite the three major leaders to jointly participate in a live programme and then broadcast whichever of them turned up on the night. The more immediate short-term impact of the programmes was to turn the focus of this campaign ever more on the characters of the main leaders. This extended to their families and most especially their partners. Gordon Brown had initially got to know his wife Sarah when she was working as a public relations adviser to Labour and she subsequently played a major role in helping to 'humanise' him by accompanying him before and during the campaign and giving interviews to attest to his personal qualities. Similarly Samantha Cameron featured prominently, talking openly about her husband to ITV journalist Sir Trevor MacDonald and frequently accompanying him during the campaign. ${ }^{i i i}$ Private Eye satirised the appearance of the 'leader's wives' in recognition that there had been something of a departure from previous elections in which partners had been seen but remained largely silent. ${ }^{\text {iv }}$ Nick Clegg's partner Miriam Gonzalez 
made a virtue of continuing working during the campaign although she too did give interviews. In the early stages of the election Clegg was more likely to be seen with a political partner, his deputy Vince Cable. Cable's image was emblazoned alongside his leader's on the Liberal Democrat battlebus in a move that underlined his perceived importance to the party going into the campaign although his presence markedly declined once the race got underway.

David Cameron had entered the campaign claiming he was the change candidate. Consequently the success of the rival opposition leader in the first debate proved especially unsettling for the Conservatives. Following the election several influential Tory commentators including donor and Vice-Chairman Lord Ashcroft and blogger Tim Montgomerie were particularly critical of the leadership for having agreed to participate in an untried format when the party had comfortably been ahead in the polls. ${ }^{\mathrm{v}}$ During the initial debate both of Clegg's opponents had sought to find common ground with him so as to appear reasonable but also as a precursor to negotiations in a hung parliament scenario. Brown's repeated utterance of the phrase 'I agree with Nick' was subsequently adopted by the Liberal Democrats as a campaign slogan. Some media pundits appeared surprised by what many now termed 'Cleggmania' although veteran commentator Robert Harris correctly anticipated heightened exposure during the campaign would enhance the Liberal Democrat appeal. Clegg's impact was further magnified because of his hitherto relatively low profile. Paddy Ashdown had supported his successor's leadership bid because of his 'extraordinary ability to communicate' but, having won the position, Clegg appeared overshadowed by fellow party MPs such as the ubiquitous Lembit Opik and Vince Cable, the economist whose forensic yet accessible analysis of the 2008 crisis generated considerable media interest. ${ }^{\mathrm{vi}}$ Consequently Clegg's lack of media visibility together with his presentational skill conspired 
to transform his public persona during and after the first debate. This was compounded by a format that afforded him equal billing despite the chance of him becoming Prime Minister being remote.

Elections have long favoured the third party and their forebears because of the broadcasters' desire to ensure greater parity between the rival contenders' share of coverage during the campaign period. ${ }^{\text {vii }}$ This was particularly the case in a close race with a strong likelihood of a hung parliament result in which the Liberal Democrats would be 'kingmakers'. But Clegg's performance in the debates added to this and the tenor of much of his party's coverage perceptibly changed and was no longer perfunctory as was often the case in past campaigns. This was growing recognition of the seriousness of the Liberal Democrats' bid for at least a share of power. An eve of first debate poll from Ipsos MORI poll reported 53\% of voters expected Cameron to do best as opposed to $20 \%$ for Brown and $12 \%$ for Clegg. The outcome was, however, very different. Populus reported $61 \%$ of their respondents agreeing that Clegg had won as opposed to $21 \%$ for Cameron and $17 \%$ for Brown. The subsequent debates provided less dramatic postmortems with the Conservative leader vying with the Liberal Democrat for the opinion poll accolade of 'winner' in instant polls of dubious reliability with ITV actually mistakenly broadcasting the raw data from one survey provided to the station by its market researchers. Overall, the series and exhaustive follow-up analysis, which featured assorted politicians, journalists and spin-doctors, promoted the 'horse race' election-as-game aspect of the campaign coverage. The BBC reinforced this by devoting considerable airtime to reporting the so-called 'worms' produced on screen when a tiny unrepresentative sample of three dozen undecided voters turned electronic dials in positive/negative response to the leaders during each of the live debates. Rather than rely on these kinds of gimmicks, a series of ITV post-debate specials hosted by 
Jonathan Dimbleby proved more informative because they enabled undecided voters to speak for themselves. ${ }^{\text {viii }}$

It is questionable how and whether the debates contributed to the final election outcome. Following Clegg's opening performance media speculation focused on whether it might provide the catalyst for his party to overtake Labour. And although this was reflected in some of the mid election polls, this apparent surge in support failed to materialise at the ballot box. This is perhaps not surprising given research on the American experience indicates earlier debates tend to have most impact and their influence is less on voting behaviour and more in terms of helping to inform the electorate about issues, candidates and their policies. ${ }^{\text {ix }}$ Arguably the key influence of the debates in the 2010 campaign was to transform the narrative of the campaign which has hitherto been preoccupied as to whether the Conservatives to win an outright majority. Clegg challenged this by highlighting his rival candidacy to those many undecided voters seeking change in government. This in turn encouraged a bifurcation in the right's message be this from the official Conservative campaign or its print media supporters.

\section{Yes We Cam: the revival of the Tory Press}

In contrast to the three elections Tony Blair won, Labour faced a more hostile press going into this campaign. The circulation of its only reliable supporter, the Mirror, was slight when compared with that of the pro-Conservative newspapers. The latter group had been inconsistent in their support for Cameron but they proved willing allies during the actual campaign. The best selling Sun had formally abandoned its Labour allegiance during the party's 2009 conference but had become a vocal critic of Gordon Brown's government sometime before. ${ }^{\mathrm{x}}$ The redtop's change of allegiance saw it rejoin the Tory press alongside 
the Mail, Express and Telegraph and together these titles launched robust attacks on Brown's character and his record (see Table 1). The other defectors to the Conservatives, The Times and Financial Times, were far more circumspect in their endorsement although their loss was a psychological blow to Labour. Interestingly the Star, despite its populist attacks on welfare 'scroungers', immigrants and such like, did not realign itself with the Conservatives, preferring to maintain its officially non-partisan stance.

Perhaps inevitably Cleggmania proved a defining moment for the press in this campaign. Some of the subsequent reaction was positive. The Independent once again backed the Liberal Democrats and this was followed by similar pledges of support from The Guardian and its Sunday sister The Observer. Their typically qualified endorsements provided a stark contrast to the more negative attention grabbing responses in the Tory press. On the eve of the second debate there was a concerted newspaper attack on the Liberal Democrat leader and his policies. The Daily Telegraph published a story suggesting Clegg had personally received payments from assorted party donors. ${ }^{\mathrm{xi}}$ He denied the claims which appeared designed to compromise his integrity through reviving memories of the MPs' expenses controversy. The Telegraph had been the paper that first broke the scandal during the preceding parliament. Clegg's personal expenses briefly surfaced in the second televised debate when Sky's moderator Adam Boulton controversially raised the matter in an apparent contravention of the extensive rules governing the format.

On the same day the Telegraph revelations appeared, the Express bitterly attacked the Liberal Democrat's 'crazy' immigration policy whilst the previous day the Sun had mocked Clegg over his pre-debate preparations. ${ }^{\text {xii }}$ But the most audacious front page was the Mail's 'Clegg's Nazi slur on Britain', a reference to a 2002 Guardian article in which the then MEP had suggested the Germans had come to terms with the Second World War in a way the 
British had not. ${ }^{\text {xiii }}$ Clegg rebuffed the coverage by joking that his public standing had gone from the level of 'Churchill to Nazi' within a week. The scale and severity of the press attacks even led to Labour's Chair of Electoral Strategy Peter Mandelson denouncing 'disgusting and classic smears... straight out of the Tory party' he ascribed to Conservative director of communications Andy Coulson, the former News of the World editor, and the 'Tory party dirty tricks manual'. ${ }^{\text {xiv }}$

The decline of newspaper sales implies press influence, such as it ever was, has declined from the 1980s when the debate over their impact was at its most intense. However some politicians still subscribe to the thesis that reporting can and does make a difference during elections. In the speech conceding her defeat Conservative Joanne Cash claimed: 'in Westminster North the media played an incredibly powerful role, and we have to beg the question what their role is going to be going forward- are they going to tell the truth or are they going to trash people and lie about their families? ${ }^{\mathrm{xv}}$ This had followed allegations relating to Cash's apparently fractious relationship with local activists published by the Mail and other newspapers who were critical of her and other so-called 'A-List' candidates whose selection had in part come about following an attempt by the leadership to bring greater diversity to the parliamentary party in terms of gender, ethnicity and sexuality. Some of those promoted in this way were subsequently dismissed by right-wing media commentators as so-called 'Cameron cuties' following their appearances in photo-shoots for glossy magazines such as Vanity Fair and Grazia, the latter of which also featured rival slates of glamorous representatives from the other major parties. ${ }^{\text {xvi }}$

Unlike broadcasters, the primary restrictions on what it is permissible for a newspaper to publish relate to the general laws covering libel. At election times, the press routinely exercise their right to pontificate on the choices available and hence the interest in 
gauging whether or not this still matters. Most shifts in readership opinion between 2005 and 2010 were broadly in keeping with the 5\% national 'swing' from Conservative to Labour (Table 2). Some of this may have been linked to declining sales or else demographic trends relating to changing gender, age, regional and class profiles of the differing titles' consumers. Nevertheless it is intriguing to note that there was a decisive 'swing' of $13.5 \%$ from Labour to Conservatives amongst Sun readers and within this evidence of a loss of support from the government to both of the main opposition parties. This marked shift may have been related to similarly disproportional changes of allegiance within some of those groups traditionally associated with this newspaper, notably the skilled working class, males of various ages and those living in certain regions. However these demographic factors alone may not account for the scale of such change. Intriguingly, this was a campaign in which the Sun revived the kind of strongly partisan stance it had not adopted since 1992, the election in which it had last endorsed the Conservatives. During the intervening years the paper's support for Blair had been uncharacteristically nuanced and more about the leader than his party: it had been a prominent part of the 'Tony' press. ${ }^{\text {xvii }} 2010$ saw something of a revival in the more strident Tory press of the kind last seen in the early 1990s. One particular aspect of this was the Sun's negative portrayal of Gordon Brown and it was partly in response to such coverage that the Prime Minister decided to take his message directly to the public in an attempt to reconnect with the electorate. This strategy would present its own risks.

One day... in Rochdale: 'Duffygate' and other awkward moments

Human interest stories have long dominated news coverage and this reflects the belief of various theorists from Graham Wallas to Drew Westen, writing a Century apart, that mass politics is guided by emotion and not just reason. ${ }^{\text {xiii }}$ Consequently more abstract topics can 
appear marginal to the election and/or media agendas. In response to this Channel 4 devoted a whole discussion to the issues it felt were being sidelined despite the extensive campaign coverage. The programme was particularly interested in the widely acknowledged debt problem afflicting the nation's economy. ${ }^{\text {xix }}$ And whilst others, notably the Institute for Fiscal Studies, attempted to press leaders on the issue, the scale and detail of the problem appeared beyond the comprehension or failed to attract the attention it arguably merited from many media outlets. This in part reflected the evasiveness of many politicians as to the level of the debt problem and how they proposed to tackle it.

A perception that the leaders were trying to avoid public scrutiny over the budgetary crisis, not to mention other issues, led to several apparently spontaneous interventions by assorted citizens. Some of them were reminiscent of Sharron Storrer who memorably confronted Tony Blair over the state of the NHS during the 2001 election. The media proved more than receptive to covering events of this kind because when voters were normally granted access to politicians there was a suspicion the former were party activists masquerading as ordinary members of the public. The cordon around politicians was symbolised in the way numerous leaders' campaign speeches were accompanied by a backdrop made up of often youthful supporters providing telegenic support to the visitor. The controlled nature of these kinds of event led one protestor to confront Gordon Brown during a meeting in the North East because the Prime Minister 'needs to see real electors, not just hand-picked people'. ${ }^{\mathrm{xx}}$

Brown's campaign tour of the country was periodically interrupted by citizens with varied grievances such as a disillusioned publican, a father angry about the lack of school places, and an anti-nuclear activist who invaded the stage during the leader's final major speech. Cameron too faced close questioning by members of the public including an anxious 
father concerned about his disabled son's educational provision. But there was nothing to match Brown's most memorable and excruciating meeting with Gillian Duffy on what had started as a routine campaign visit to Lancashire. The encounter with the disillusioned Labour supporting Mrs Duffy had ended warmly. But when Brown returned to the privacy of his car having failed to return his wireless microphone to the Sky News team following him his subsequent conversation with an aide was recorded and broadcast without either of them aware they were being monitored. Brown's dismissal of 'that woman' with her 'bigoted' views dominated subsequent news bulletins with even the most populist Channel 5 programme devoting 10 minutes to the gaffe despite having largely avoided trailing the election as a lead item.

A recurrent feature of the 'Duffygate' coverage was Brown's seemingly despairing, head in hands, reaction to hearing the recorded conversation as a guest on BBC Radio 2's Jeremy Vine. Mrs Duffy's shocked reaction was also broadcast together with her objection to being labelled 'that woman'. Brown's campaign plans were effectively derailed as he opted to visit Mrs Duffy at her home, which was now besieged by reporters, to personally apologise for his comments. The voter eventually broke her silence in a Mail on Sunday interview in which she confirmed her intention to abstain in the election. ${ }^{\mathrm{xxi}}$ The incident was damaging to Brown but could have been worse as was noted by one of his most prominent media critics Andrew Rawnsley of The Observer. Rawnsley, who featured prominently in the extensive journalistic analysis of Duffygate (which was also known as 'Bigotgate'), argued the incident was comparatively mild in comparison to some of the examples of the Prime Minister's dysfunctional behaviour discussed in his recent book. ${ }^{\text {xxii }}$ 


\section{Conclusions}

Despite the hype surrounding the idea of the Internet election what dominated the campaign was the traditional platform of broadcasting. The leadership debates, whilst not necessarily influencing the outcome of the election, certainly helped shape the narrative of the campaign by elevating the status of the Liberal Democrat leader. The outburst of socalled Cleggmania triggered a strong response from Conservative supporting newspapers. How successful this reporting was is more questionable, since the long-term decline in press sales has arguably seen a diminution of their collective hold on the news not to mention the British psyche. This was revealed in the almost mocking reaction of other media commentators when there was a simultaneous but hardly spontaneous burst of criticism levelled at Nick Clegg by the Tory press. Their belated enthusiasm for attacking opponents of the Conservatives was something of a departure from their previously studied indifference towards the third party. 
Table 1: Editorial declarations and circulations (in millions) of the national newspapers ${ }^{\mathrm{xxiii}}$

\begin{tabular}{|l|l|l|l|l|}
\hline & & & & \\
\hline Daily Press & 2010 & Circ & 2005 & Circ \\
\hline The Guardian & Moderate Lib Dem & 0.29 & Weak Labour & 0.34 \\
\hline The Independent & Moderate Lib Dem & 0.19 & Moderate Lib Dem & 0.23 \\
\hline The Times & Weak Conservative & 0.51 & Weak Labour & 0.65 \\
\hline The Telegraph & Moderate Conservative & 0.68 & Strong Conservative & 0.87 \\
\hline The Financial Times & Very Weak Conservative & 0.39 & Very Weak Labour & 0.38 \\
\hline The Daily Express & Very Strong Conservative & 0.67 & Strong Conservative & 0.87 \\
\hline The Daily Mail & Strong Conservative & 2.10 & Strong Conservative & 2.30 \\
\hline The Sun & Strong Conservative & 3.00 & Weak Labour & 3.26 \\
\hline The Mirror/Record & Strong Labour & 1.57 & Strong Labour & 2.29 \\
\hline The Star & No Preference & 0.82 & No Preference & 0.85 \\
\hline
\end{tabular}


Table 2: Readership Allegiances of Newspapers 2010 (\& 2005)

\begin{tabular}{|l|l|l|l|l|}
\hline Daily Press & Lab & Cons & LD & Swing \\
\hline Result & $29(35)$ & $36(32)$ & $23(22)$ & 5 Lab-Con \\
\hline The Guardian & $46(43)$ & $9(7)$ & $37(41)$ & 3.5 (LD-Lab) \\
\hline The Independent & $32(34)$ & $14(13)$ & $44(44)$ & 1.5 \\
\hline The Telegraph & $22(27)$ & $49(38)$ & $24(26)$ & 8 \\
\hline The Star & $7(13)$ & $70(65)$ & $18(17)$ & 5.5 \\
\hline The Daily Express & $35(54)$ & $21(22)$ & $15(20)$ & 10 \\
\hline The Daily Mail & $19(28)$ & $53(48)$ & $18(18)$ & 7 \\
\hline The Sun & $16(22)$ & $59(57)$ & $16(14)$ & 4 \\
\hline The Mirror & $28(45)$ & $43(33)$ & $13.5(12)$ & 13.5 \\
\hline
\end{tabular}

\footnotetext{
${ }^{\mathrm{i}}$ Figures from Broadcasting Audience Research Board. There were also other debates featuring other senior frontbench politicians debating their particular issues mainly on BBC during the election. There was also a Chancellors' debate on Channel 4 just prior to the formal campaign.

ii The 2010 Labour leadership election has been in part framed by considerations as to how the five contenders might fare in a live debate situation.

iii Trevor MacDonald meets David Cameron, ITV, 15.3.10.

${ }^{\text {iv }}$ Private Eye, 13.4 .10

${ }^{v}$ Conservativehome.blogs.com/generalelectionreview.

${ }^{v i}$ The Guardian 18.10.07. Opik lost his seat in this election, a shock result in part attributed to his personal celebrity.

vii Blumler, J. and McQuail, D. Television in Politics, Faber \& Faber: London, 1968.

viii Campaign 2010 with Jonathan Dimbleby, ITV 15.4.10

ix The authors are very grateful to fellow contributor Jane Green for guidance on the impact of debates and for suggesting the following review of the literature, Beniot, W.L. et al., A meta-analysis of the effects of viewing US presidential debates, Communication Monographs, 70: 4, pp.335-50.

${ }^{x}$ Sun 30.9.09

${ }^{x i}$ Daily Telegraph 22.4.10.

xii Daily Express, 22.4.10 and Sun, 21.4.10.

xiii Daily Mail, 22.4.10.

xiv The Guardian 23.4.10

${ }^{\mathrm{xv}}$ www.timesonline.co.uk, 07.5.10

${ }^{x v i}$ Daily Mail 14.4.10
} 
xvii Deacon, D. and Wring, D. 'Partisan Dealignment and the British Press', in J. Bartle et al. (eds), Political Communications: the British General Election of 2001. Ilford: Frank Cass, 2002

xviii Wallas, G. Human Nature in Politics, London: Constable; Westen, D. The Political Brain, Tennessee: Public Affairs, 2007.

${ }^{x i x}$ Election Uncovered, Channel 4, 2.5.10

${ }^{\mathrm{xx}}$ Daily Telegraph, 2.5.10

xxi Mail on Sunday, 2.5.10

xxii Rawnsley, A., The End of the Party, Viking: London, 2010.

xxiii The partisanships of the given newspapers are determined by the statement declaring their allegiance normally published on or near polling day. For more on this see David Deacon and Dominic Wring, 'Patterns of Press Partisanship in the 2010 General Election’, British Politics, forthcoming. 